\title{
AN ANALYSIS OF SPEECH FUNCTION AT TRADITIONAL SHOPPING CENTER IN LANGSA
}

\section{Irma Dewi Isda}

Universitas Samudra, Langsa, NAD

irmaisda.fkip@unsam.ac.id

\section{ABSTRACT}

This study deals with Speech function at traditional shopping center in Langsa. The objectives of this study are to find out the types of speech function, the most dominant type of speech function used, and the meaning of the dominantly used. The research of this study was carried by using descriptive qualitative. The data were taken from ten sales and buyers conversation using longer and short conversation at traditional shopping center. The data were analyzed and classified into four types of speech functions namely statement, question, offer, and command. The findings indicated based on longer and short conversation there are statement $43(40,18 \%)$, question $53(49,53 \%)$, offer $7(6,5 \%)$, command 4 $(3,73 \%)$ while on short conversation are statement $13(30.9 \%)$, Question $22(52,3 \%)$, offer $5(11,9 \%)$ and Command $2(4,7 \%)$. Question as the most dominant type of speech function used in sales and buyers on both conversation. It means questions always happened in the traditional shopping center to give demand and information.

\section{Keywords}

Speech Function, Communication, Traditional Shopping Center

\section{INTRODUCTION}

Language is learned and shared by human being in the same speech community. It will explore and develop rapidly from time to time. Moreover, the studying of language from its function perspective is interested by sociologists, psychologists, and sociolinguists. Therefore sociolinguistics is the science that handled by sociolinguists. According to Janet Holmes (2001) 
sociolinguistics is a study of relationship between language and society which speaking in different social contexts and identifying language of social functions can be considered by sociolinguistic.

Based on the explanations above, the writer believes that sociolinguistic is a study of linguistics which language is influenced by society, although in other side socio also determines language. Essentially it does not discuss about structure of language, but it focuses on how language is used in the rules of speaking way in different communities that clearly quite distinctive in a range of areas. Afterward, the role of sociolinguistic is managing a language as its functions in society.

There are two form of communication. It is written and spoken. Written consist of novel, drama, magazine, short story, and newspaper. And the spoken include; debate, dialogue, conversation and interview. Language can form as conversation that becomes very important matter in communicating and interacting with others. A conversation can take place in one place and there must be a contact between two participants; those are speaker and hearer.

Halliday (1994) states that when exchanging and expressing ideas, human being performs two roles namely giving and demanding, for the commodity such as information and goods or services. In systemic functional linguistic (SFL), it is named speech function. Speech function is a way of someone delivers ideas in communication to make listeners understand the ideas well. It is done to convey idea like, statement, question, offer and commands. They are namely kinds of speech function. 
The writer also want to give the deeply explanation about speech functions which contain of two parts they are giving and demanding which are the essence of communication must be noticed well to avoid misunderstandings occur towards the speaker and the listener that happened in traditional shopping center in Langsa. When the speaker utters something through question, he is actually requiring the listener to receive it. While requiring give information when he utters something through command or offer.

The writer is interested in studying a speech function because so many conversations happened at traditional shopping center especially in Langsa, the exchange process structure and speech functions are much related to each other. It realizes the role relationship of the sellers and buyers. There is also a correlation between the structure of a responding move and the different structure of an initiating move.

For example, there is a conversation of transaction between buyer and seller at shoes-shop.

Buyer : May I see that pink shoes sister?

Seller : yes you may

Buyer : How much it costs?

Seller : Only sixty thousand ruphias.

Based on the conversation above there are two basic types of speech functions related to the nature of the commodity being exchanged. This may be either (a) good-\&-services or (b) information. As describe at the example the writer found any question and statement between seller and buyer at that 
conversation. When the buyer utters something through question, he is actually requiring the seller to receive it. While requiring gives information when he utters something through command, statement or offer.

In this research, the writer is interested in conducting research about "An Analysis of SpeechFunction at Traditional Shopping Center in Langsa”.

\section{LITERATURE REVIEW}

\section{Sociolinguistics}

Language is learned and shared by human being in the same speech community. It will explore and develop rapidly from time to time. Moreover, the studying of language from its function perspective is interested by sociologists, psychologists, and sociolinguists. Therefore sociolinguistics is the science that handled by sociolinguists.

According to Janet Holmes (2001) sociolinguistics is a study of relationship between language and society which speaking in different social contexts and identifying language of social functionscan be considered by sociolinguistic.Based on the explanations above, the researcher believes that sociolinguistic is a study of linguistics which language is influenced by society, although in other side socio also determines language. Essentially it does not discuss about structure of language, but it focuses on how language is used in the rules of speaking way in different communities that clearly quite distinctive in a range of areas. Afterward, the role of sociolinguistic is managing a language as its functions in society.

However, Rajend Mesthrie et al. (2000:5) describe in their book which concern about the "Human Communication" that: "Aspect within the definition of language implies attention to the way language is played out in 
societies in its full range of functions. Language is not just denotation, a term which refers to the process of conveying meaning, referring to ideas, events orentities that exist outside language".

Moreover, Chaer and Agustina (2004) describe that human in community, institutions, and social process is as an object of sociology that can be discovered such as, to understand how the human can adapt the environment.

\section{Functional grammar}

Functional Grammar views language as source for making meaning. Halliday (1994) states language is a system of meaning. When people use language, their language act contains the expression of meaning. Functional grammar is an application function approach that shows language first and the system of communication and also sees how the grammar itself is organized to allow the speakers or the writers to exchange meaning.

Textual function is when the language is organized in written to the real world and any other linguistic events. Interpersonal function is when the language is used to enable people to participate incommunicative acts with other people, to express and to understand their feelings, attitude and judgments.

According to Gerot and Wignell (1994), interpersonal function refers to a speaker's attitudes and judgments. These are meaning for acting upon the language with others. There are two levels of interpersonal function: they are speech function and mood. At the level of discourse and semantics, human being performs two roles namely Giving and Demanding. The commodity exchanged may be either information or Goods and Services as explained as follow: 
Giving $/$ information $=$ statement $(\mathrm{S})$

Demand $/$ information $=$ question $(\mathrm{Q})$

Give $/$ goods and services $=$ offer $(\mathrm{O})$

Demand $/$ goods and services $=$ command $(\mathrm{O})$

\section{Metafunction}

Metafunction is the function of language based on human use of the language. The meaning of metafunction is to represent, to exchange, and to organize experiences. These metafunctions technically are termed as ideational, interpersonal, and textual function.

\section{Interpersonal metafunction}

Paziraei (2013) states that the interpersonal metafunction shows the way the addressor and the addressee interact and how they use the language to maintain the relations between them. During a conversation the addresser may give something to the addressee or ask something from the addressee. This metafunction is an exchanging.

This exchanging may be an offer, a command, a declarative, or an interrogative. The interpersonal function is realized at two levels namely at the level of semantics and lexicogrammar which is term mood. At the level of semantic human being perform two roles namely giving and demanding. The commodity exchange may be either information or goods and services.

Yipei and Lingling (2013) states that delivering a speech is a typical interpersonal activity, and whether a speech succeeds or not, to a large degree, depends on the way speaker intrudes himself into the interaction. How to arouse audience interest and enthusiasm is the key point. 


\section{Speech functions}

Ye (2006) states that speech functions are an action or performance done by language users such as asking, commanding and answering in order to fulfil the intention of the speakers and listeners. Speech functions are used as the medium exchanging experiences in order to fulfil their needs.

Sulistyowati (2010) states that to communicate effectively, we should clearly organize the messages that we want to convey through conversation. The organization of messages involves giving and demanding and this exchange might be more complicated than it seems. If we are demanding something, it means we are inviting to give, and if we are giving something, it means we are inviting to receive.

Halliday (1994) states that the most fundamental types of speech functions, which lie behind all the more specific types, are just two (1) giving and (2) demanding. Either the speaker is giving something to the listener or he is demanding something from him. Even these elementary categories already involve complex notions i.e. giving means 'inviting to 40 receive', and demanding means 'inviting to give'. The speaker is not only doing something himself, but s/he also requiring something of the listener. These two basic types of speech functions related to the nature of the commodity being exchanged. This may be either (a) good-\&-services or (b) information, as described in following table

Janet Holmes (2001) said that:“The different speech communities emphasize different function, and express particular functions differently. It is due to linguistic politeness is culturally determined and clearly rules for polite behavior differ from one speech community to another"(p.258). Meanwhile, language is used to perform some kinds of communicative acts, 
like making a request or offering advice. It is well-known as fundamental exponents. On the other hand, examining the way of using language in social contexts provides a wealth of information about the way language works, as well as social relationships in a community and signal aspect of our social identity through our language (Janet Holmes, 2001). However, the way of talk is influenced by the social context. It matters will be appeared when talking or feeling about something. Although same message may be expressed very differently to the others, like as the use of different styles in different social contexts. Furthermore, the following any utterance may be expressed more than one function, and any function may be expressed by a stretch of discourse which doesn't exactly coincide with an utterance is conveyed by Janet Holmes (2001). The explanations above tell the researcher that speech function is the speech even where language have a function to deliver a message from addressers to addressees byvarious types based on the situation or topic of message.

\section{Types of speech function}

a. Statement

Grolier (1992) states that statement is a way of giving information by stating or the act of stating in speech and writing. Statement can be positive and negative. Statement is usually begun with subject, followed by verb or auxiliary verb and ended by full stop.

Formula: Subject + verb/aux

For example:

- I think it is suitable for you

Subject Verb_Statement 


\section{b. Question}

Grolier (1990) states that question is an interrogative question which is used to seek confirmation or to ask something or an inquiry that invites or calls for reply. Question is a way of demanding information in the form of interrogative statement that may be either information question (whquestion) or yes/no question and which inquire reply from listener. A question begins with auxiliary verb or WH-Question and will be ended with question mark (?)

Formula: aux. V or wh-question $+\mathrm{S}+\mathrm{V}+$ question mark (?)

For example:

What color do you want?

WH question Subject Verb__ Question

\section{c. Offer}

Grolier (1992:268) states that offer as an expression of willingness to give or do something, or to put forward for acceptance, rejection. Offer also can be definitude as a way of giving good and service to someone. Offer is usually begun with modal and always ended with a question mark (?).

Formula: modal $+\mathrm{S}+\mathrm{V}$

For example:

Would you like to take that dress?

Modal Subject Verb Offer 
d. Command

Grolier (1992) states that command is a way to receive information, good or service by forcing the listener to give them. Command also is a way of demanding good and service in form of imperative statement whether in the form of positive or negative command. In command sentences, the subject is omitted. It is begun with the predicate and it is usually ended with exclamation mark (!).

Formula: Verb + Object + Exclamation mark (!)

For example:

Take a look that shoes!

Verb Object Command

The four type of speech function of statement, question, offer and command find their realization in mood (declarative, interrogative and imperative) which is an aspect of interpersonal meaning at the level of lexicogrammar. All the speech functions have marked representative of mood except offer.

Saragih (2010) states that in act interaction, the speech function is in initiated by speaker (addresser) and then the listener (addressee) responds to the speech function.

Speech function recognize a correlation between the different structure of an initiating move and the structure of a responding move; position and negative responding speech function. 


\section{RESEARCH METHOD}

The research of this study was carried by using descriptive qualitative. In this descriptive study, the writer used qualitative research. Taylor and Bogdan (2000) state that qualitative research aims to present rich descriptions of phenomena. The data were taken from ten sales and buyers conversation using longer and short conversation at traditional shopping center in Langsa.

The techniques of collecting the data were observation and documentation. The writer observed and listened directly to the buyers' and seller's conversation to get data. The writer acted as the observer who used a blank sheet of paper, recording instrument, and camera to record the buyers' and seller's activities during the observation. In documentation, the writer also used some document to analyze the research such as conversation recording, photos and other documents which were needed. In data analysis the researcher used interpretative approach like, identification step, classifying data and analyzing the data.

\section{FINDING AND DISCUSSION}

The data are collected from the longer and short conversation at Traditional shopping center in Langsa. 


\section{Figure I}

Speech function on longer conversation

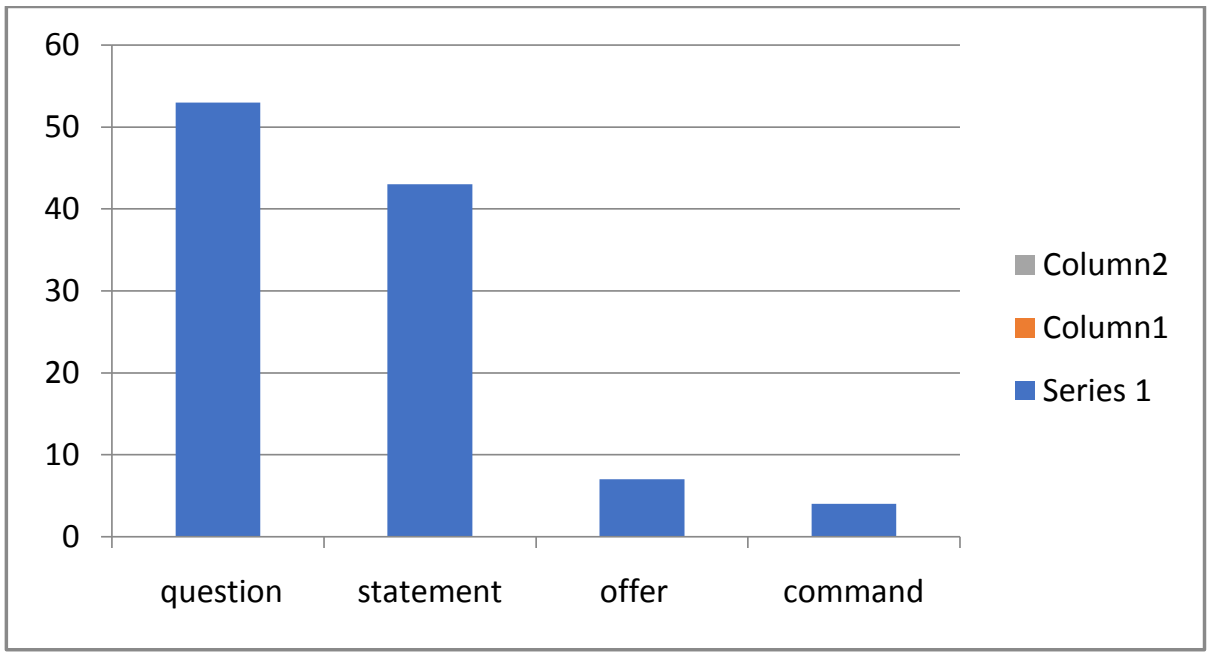

Note:

Question : 53

Statement : 43

Offer $\quad: 7$

Command : 4

The figure I, shown that the total number of speech function was 107. Question as the dominantly used at traditional shopping center in Langsa and then followed by statement (43), offer (7) and command (4). 
Figure II

Speech function on short conversation

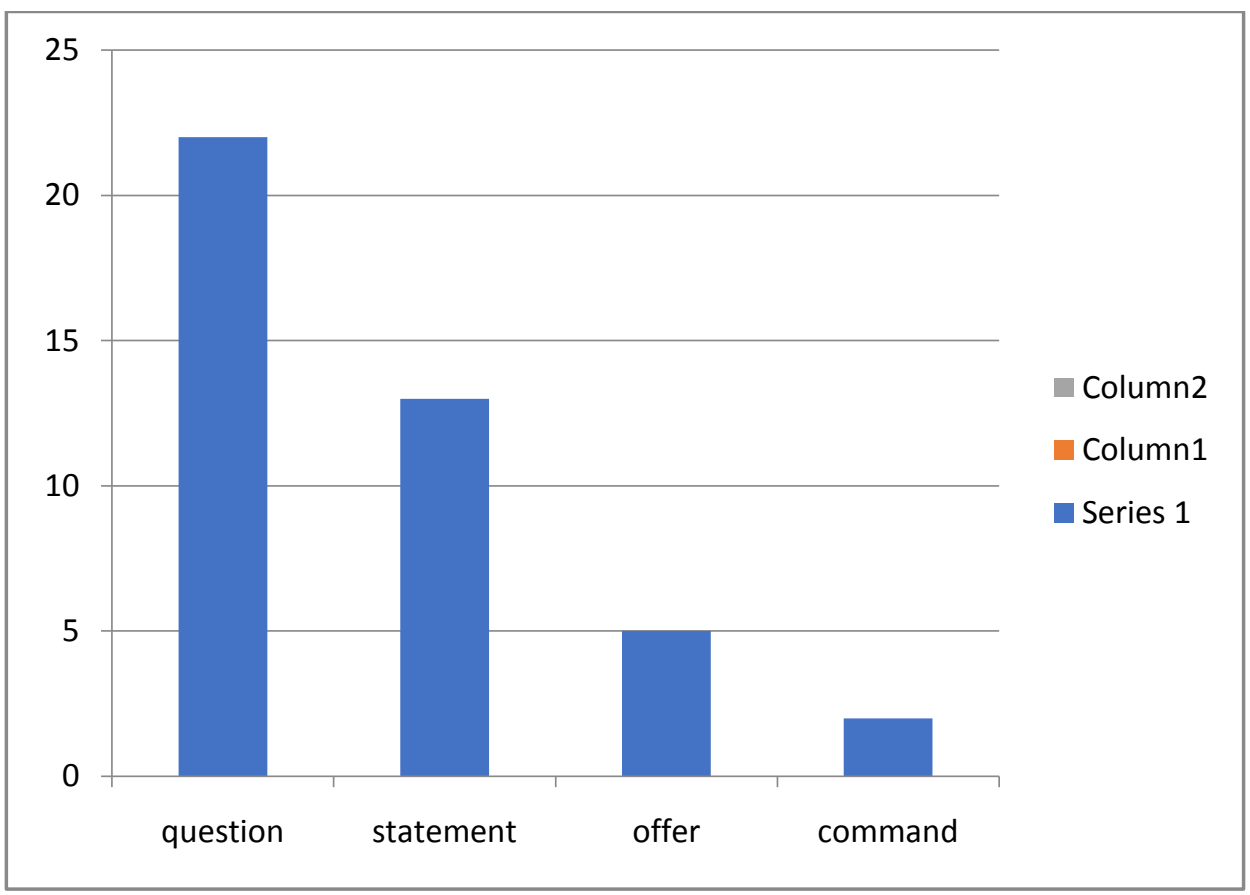

Note:

Question : 22

Statement : 13

Offer $\quad: 2$

Command $\quad: 5$

The figure II, shown that the total number of speech function was 42. Question as the dominantly used at traditional shopping center in Langsa and then followed by statement (13), command (5) and offer (2). 
Table I

The percentage of speech function found on the longer conversation

\begin{tabular}{|l|l|l|l|}
\hline No & Types of speech function & Number (F) & Percentage \% (x) \\
\hline 1 & Statement & 43 & $40,18 \%$ \\
\hline 2 & Question & 53 & $49,53 \%$ \\
\hline 3 & Command & 4 & $3,73 \%$ \\
\hline 4 & Offer & 7 & $6,5 \%$ \\
\hline & Total & 107 & $100 \%$ \\
\hline
\end{tabular}

From the table I, the percentage of statement was 40,18\%, Question was $49,53 \%$, Command was 3,73\%, and Offer was $6,5 \%$. There were 4 speeches that writer analyzed. From 4 speeches, there were 107 sentences of speech function found at the longer conversation between sellers and buyers at traditional shopping center in Langsa. The speech function dominantly used was question (49,53\%). The highest proportion in the use of speech functions due to the fact that speech deals with give demand and information to the sellers and buyers.

Table II

The percentage of speech function found on the short conversation

\begin{tabular}{|l|l|l|l|}
\hline No & Types of speech function & Number $(\mathrm{F})$ & Percentage \% (x) \\
\hline 1 & Statement & 13 & $30,9 \%$ \\
\hline 2 & Question & 22 & $52,3 \%$ \\
\hline
\end{tabular}


Journal of Linguistics, Literature \& Language Teaching

\begin{tabular}{|l|l|l|l|}
\hline 3 & Command & 5 & $11,9 \%$ \\
\hline 4 & Offer & 2 & $4,7 \%$ \\
\hline & Total & 42 & $100 \%$ \\
\hline
\end{tabular}

From the table II, the percentage of statement was 30,9\%, Question was $52,3 \%$, Command was $11,9 \%$, and Offer was $4,7 \%$. There were 4 speeches that writer analyzed. From 4 speeches, there were 42 sentences of speech function found at the shorter conversation between sellers and buyers at traditional shopping center in Langsa. The speech function dominantly used was question $(52,3 \%)$. The highest proportion in the use of speech functions due to the fact that speech deals with give demand and information to the sellers and buyers.

\section{DISCUSSION}

After collecting and reading the data, they were classified based on the four types of speech functions at traditional shopping center in Langsa. There were 107 speech functions found on the longer conversation and 42 speech functions found on the shorter conversation. Here some examples of representative data based on the types of speech functions.

\section{Statement}

Statement as a speech function has a purpose to give information. This speech function is used to express the speaker's ideas or to ensure and receive that information. 
The example of statement can we see below:
a. $\quad$ think fifty five thousand is cheapest than others
$\mathrm{S} \quad \mathrm{V} \longrightarrow$ Statement
b. I choose the pink color shoes
$\mathrm{S} \quad \mathrm{V} \longrightarrow$ Statement
c. I want two kilos of sugar

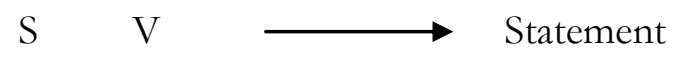
d. $\frac{\mathrm{I}}{\mathrm{S}} \underset{\mathrm{V}}{\stackrel{\text { buy }}{\longrightarrow} \text { one kilo of oranges first }}$ Statement

Fourth of the examples are statement. The sentence is started by subject followed by verb. It is mean that statement used by the sellers and buyers to give information

2. Question
a. How much $\frac{\text { it cost? }}{\text { WH question }+\mathrm{S} \mathrm{V}}$
b. $\frac{\text { How about }}{\text { WH question }} \frac{\text { if I take two pieces? }}{\text { if clauses }} \frac{\text { May }}{\text { aux }} \frac{\text { it is fifty thousand? }}{\mathrm{S}} \rightarrow$ Question
c. Which one do you like?
Preference Auxiliary $\longrightarrow$ Question
d. Are there flat shoes here?
Demonstrative object $\longrightarrow$ Question

Fourth of the examples are question. The sentence is started by WH question followed by $\mathrm{S}$ than verb or if clause and there is a sentence started by preference and demonstrative. It is mean that question used by the sellers and buyers to give demand and ask information. 


\section{Offer}

In the conversation, "offer" is a kind of basic speech function move which is initiated only by the speaker.
a. ...but a flat shoes is good for you
Coor.conj independent clause $\longrightarrow$ Offer
b. Come on sister and brother there is discount here Verb phrase Subject $\longrightarrow$ Offer
c. ...two kilos of chili only ten thousand, grab it fast

Noun phrases compliment $\longrightarrow$ Offer
d. Would youlike to give me the cheaper price for this scrab? Modal Subject V

Fourth of examples are offer. The sentence is started by phrases followed by $\mathrm{S}$ or sentence started by modal followed by subject and sometimes the sentence starts with compound sentence. It is mean that offer used by the sellers and buyers giving goods and services.

\section{Command}

As a speech function, command has the purpose to demand goods and services in a conversation. We can say that command function is to ask someone to do something.
a. Take a look the pink shoes over there.
Verb Phrase
Object
Command
b. Give me the twenty nine size of that shoes

$\mathrm{V} \quad \mathrm{S} \quad$ Object $\longrightarrow$ Command


Both of examples are command. The sentence is started by $\mathrm{V}$ followed by $\mathrm{S}$ or object. It is mean that command used by the sellers and buyers to ask someone to do something.

\section{CONCLUSION}

After analyzing the types of speech function at traditional shopping center in Langsa, there are four speech functions that the writer found; they are Statement, Question, Command, and Offer. The findings indicated based on longer and short conversation there are statement $43(40,18 \%)$, question $53(49,53 \%)$, offer $7(6,5 \%)$, command $4(3,73 \%)$ while on short conversation are statement 13 (30.9\%), Question 22 (52,3\%), offer 5(11,9\%) and Command 2(4,7\%). Question as the most dominant type of speech function used in sales and buyers on both conversation. It means questions always happened at the traditional shopping center in Langsa to give demand and information.

\section{REFERENCES}

Gerot, L. \& Wignel, P. (1994). Making sense of functional grammar, an introduction workbook. Sydney : Gerd Stabler.

Grolier, A. (1992). New Webster's dictionary. Connecticut: Grolier.

Hadi, M. S. (2012). An analysis of buyers' and seller's speech acts in daily transactional communication at Kebumen traditional market in Banyubiru.(Thesis, STAIN Salatiga, 2012). Retrieved from https://docplayer.net/29553579-Ananalysis-of-buyers-and-seller-s-speech-acts-in-daily-transactionalcommunication-at-kebumen-traditional-market-in-banyubiruthesis.html

Halliday, M.A.K. (1994). An Introduction to Functional Grammar (2 ${ }^{\text {nd }}$ ed). London: Edward Arnold. 
Holmes, J. (2001). An introduction to sociolinguistics. London and New York: Longman

Nurhidayah. (2012). The analysis of Speech Function Used by English Teachers' Instruction at SMP N 6 Salatiga in the Academic Year of 2011/2012. (Thesis, IAIN Salatiga, 2012).

Paziraie, M. E. (2013).The Use of Interpersonal Metafunction in Conversation Management by EFL Learners. Open Journal of Education, $1(2)$.

Saragih, A. (2010). Introduction Systematic Functional Grammar. Medan: State University of Medan (Unpublished).

Sulistyowati, T. (2011). The speech function in the conversations between the fourth semester English department students of Muria Kudus University and some foreigners. English Education Journal,1(1). Retrieved from: https://journal.unnes.ac.id/sju/index.php/eej/article/view/149

Ye, R. (2006). The Interpersonal Metafunction analysis of Barack Obama's Victory Speech. English Language Teaching Journal, 2(3).

Yipei, N. \& Lingling, L. (2013). Investigating the interpersonal and textual meaning of Steve Jobs' Stanford speech in terms of Hyland's metadiscourse theory. International Journal of Language and Linguistics, 1(4). 